\title{
Raport o stanie gminy i debata nad nim w świetle niemieckiej koncepcji demokracji kooperacyjnej
}

\section{Wprowadzenie}

Przyjęta na początku 2018 r. ustawa o zmianie niektórych ustaw w celu zwiększenia udziału obywateli w procesie wybierania, funkcjonowania i kontrolowania niektórych organów publicznych ${ }^{1}$ dokonała m.in. istotnej zmiany $\mathrm{w}$ przepisach ustaw ustrojowych, $\mathrm{tj}$.: o samorządzie gminnym $^{2}$, o samorządzie powiatowym ${ }^{3}$ i o samorządzie województwa ${ }^{4}$. Wprowadzone zmiany mają się przyczynić do zapewnienia społecznościom lokalnym większego udziału w funkcjonowaniu jednostki samorządu terytorialnego (dalej „j.s.t.") i odpowiedzialności obywateli za wspólnotę samorządowa, w której zamieszkują. Przepisy te ustanowiły

* Danuta Biniasz-Celka, mgr, Uniwersytet im. Adama Mickiewicza w Poznaniu, e-mail: dankacelka@onet.pl,https://orcid.org/0000-0001-6306-6152.

${ }^{1}$ Ustawa z dnia 11 I 2018 r. o zmianie niektórych ustaw w celu zwiększenia udziału obywateli w procesie wybierania, funkcjonowania i kontrolowania niektórych organów publicznych (Dz.U. poz. 130), dalej "z.u.o.u.”.

${ }^{2}$ Ustawa z dnia 8 III 1990 r. o samorządzie gminnym (tekst jedn. Dz.U. 2020, poz. 713), dalej „u.s.g.".

${ }^{3}$ Ustawa z dnia 5 VI 1998 r. o samorządzie powiatowym (tekst jedn. Dz.U. 2020, poz. 920).

${ }^{4}$ Ustawa z dnia 5 VI 1998 r. o samorządzie województwa (tekst jedn. Dz.U. 2019, poz. 512).

${ }^{5}$ Uzasadnienie poselskiego projektu ustawy o zmianie niektórych ustaw w celu zwiększenia udziału obywateli w procesie wybierania, funkcjonowania i kontrolowania niektórych organów publicznych, druk sejmowy nr 2001/VIII kadencja. 
obowiązek przedstawienia radom organów stanowiących j.s.t. raportu o stanie gminy, który jest formą prezentacji zagadnień wymienionych w art. 28aa ust. 2 ustawy o samorządzie gminnym: „raport obejmuje podsumowanie działalności wójta w roku poprzednim, w szczególności realizację polityk, programów i strategii, uchwał rady gminy i budżetu obywatelskiego". Pomimo że instytucja raportu dotyczy wszystkich trzech ustaw ustrojowych, to niniejsze opracowanie odnosi się do gminy, czyli tego samorządu, który jest najbliżej mieszkańców i na którym spoczywa najwięcej spraw wpływających na jakość ich życia. Poza obowiązkiem corocznego przedstawiania radzie raportu o stanie gminy niezbędna jest debata. Zaakcentowania wymaga fakt, że ustawodawca udział w debacie umożliwił nie tylko radnym (art. 28aa ust. 5 u.s.g.), ale także mieszkańcom gminy (art. 28 aa ust. 7 u.s.g.). Udział mieszkańców w debacie należy postrzegać jako przestrzeń kształtowania obywatelskości, w której jest miejsce na społeczną komunikację i dyskusję. Możliwości, jakie stworzył ustawodawca, mają zachęcić mieszkańców do większego zainteresowania się i przejmowania odpowiedzialności za lokalne środowisko i podejmowane w nim działania. Oprócz tego dają szansę bezpośredniego komunikowania się organów wykonawczych ze społeczeństwem, a zarazem zwiększają skuteczność działań ze strony włodarza gminy. Nadto, zdaniem autora opracowania, nowe mechanizmy mogą mieć wpływ na rozwój j.s.t.

Wobec przeświadczenia, że włączenie mieszkańców w sprawy publiczne ma istotne znaczenie zarówno dla kreowania społeczeństwa obywatelskiego, jak i dla rozwoju gminy, instytucji raportu nie należy postrzegać wyłącznie jako instrumentu wzmocnienia pozycji rady gminy wobec wójta ${ }^{6}$. Paradoksalnie instytucja ta może wzmocnić także pozycję wójta.

Podążając śladami niemieckich rozwiązań oddziaływania na sprawy lokalne, w opracowaniu podjęto próbę przedstawienia instytucji raportu jako koncepcji demokracji kooperacyjnej. Od organów gminy oczekuje się działań wpływających na poprawę jakości życia mieszkańców i dlatego pożądane byłoby, aby we wspólnocie lokalnej jej władze znalazły partnera, który aktywnie i odpowiedzialnie współuczestniczy

${ }^{6}$ W. Baranowska-Zając, Obowiązek przedstawienia raportu o stanie gminy jako instrumentu wzmocnienia pozycji rady gminy wobec wójta (burmistrza, prezydenta miasta), "Samorząd Terytorialny" 2019, nr 4, s. 7, LEX nr 151349430; W. Witalec, Raport o stanie jednostki samorządu terytorialnego jako instrument oceny działalności jej organu wykonawczego , "Finanse Komunalne" 2019, nr 9, s. 8, LEX nr 151354933. 
w podejmowaniu decyzji dotyczących przecież jej spraw. Czy zatem postrzeganie debaty jako koncepcji demokracji kooperacyjnej może odkryć nową formę zaangażowania obywatela w funkcjonowanie jego wspólnoty lokalnej? Odpowiedź na tak postawione pytanie stanowi podstawowe założenie poczynionych rozważań.

\section{Raport o stanie gminy - ogólna charakterystyka instytucji}

Instytucja raportu nie pojawiła się wraz z ustawą o zwiększeniu udziału obywateli w procesie wybierania, funkcjonowania i kontrolowania organów publicznych. Funkcjonowała w j.s.t. znaczenie wcześniej. Była to zarówno domena większych, jak i mniejszych miast, czego przykładami są m.in.: raport o stanie miasta Krakowa za rok $1991^{7}$ czy raport o stanie miasta i gminy Śrem za lata 1990-1994. Dotąd jednak nie istniał ustawowy obowiązek przedstawienia raportu przez organ wykonawczy ani rozpatrzenia go przez organ stanowiący i zorganizowania nad nim debaty z udziałem mieszkańców gminy. Zarówno to, czy był w ogóle przygotowywany, jak i to, jaką treść zawierał oraz w jaki sposób był rozpatrywany, pozostawiono władzom lokalnym samorządu. W związku z powyższym samorządy postępowały różnie. Niektóre raportowały co roku, a inne traktowały raport jako résumé mijającej kadencji. Co więcej, pewne raporty były bardzo szczegółowe i zawierały obszerne informacje statystyczne, a drugie były ogólne i lakoniczne. Na uwagę zasługuje fakt, że nie zawsze były upubliczniane. Niewątpliwie więc nowa regulacja ustawowa dąży do nadania raportom charakteru obligatoryjności i minimalnego zakresu treści wskazanej w ustawie.

Instytucja raportu o stanie gminy, jak już wspomniano we Wprowadzeniu, jest formą prezentacji wymienionych w art. 28aa ust. 2 u.s.g. zagadnień lub też dodatkowo innych, o których mogą zdecydować radni, podejmując uchwałę w sprawie szczegółowych wymogów dotyczących raportu (art. 28aa ust. 3 u.s.g.). Wydaje się, że w treści takiej uchwały nie jest możliwe ujęcie wszelkich elementów, jakie w danych okolicznościach, $\mathrm{w}$ danym roku i w danej gminie powinny zostać podane dla oceny działalności wójta czy oceny stanu gminy. Ponadto, w zależności od pozycji wójta

\footnotetext{
${ }^{7}$ https://www.bip.krakow.pl/?dok_id=29176

${ }^{8} \mathrm{http}: / /$ www.srem.pl/getattachment/Dla-mieszkanca/O-Sremie/Raport-o-stanie-gminy/1990-1994-raport.pdf.aspx
} 
w radzie gminy, w przedmiotowej uchwale mogą zostać zaakcentowane sprawy o charakterze uznaniowym, niedające się obiektywnie zmierzyćc ${ }^{9}$.

W praktyce mogą wystąpić różnice między raportami, co jest uzasadnione, gdyż każda gmina ma własną specyfikę. Ważne jest, aby możliwości, jakie stworzył ustawodawca zarówno organom gminy, jak i mieszkańcom, pozwalały adekwatnie do potrzeb lokalnych kształtować politykę wobec zamierzonych celów i planów. Z pewnością raport powinien w sposób rzetelny informować o efektach działań samorządu, nie powinien być natomiast propagandą sukcesu. Niewątpliwie dobrą stroną raportu jest to, że każdego roku mieszkaniec będzie miał świadomość progresu lub regresu stopnia zaspokajania jego potrzeb. Można mieć tylko ostrożną nadzieję, że raport nie będzie elementem walki politycznej w ramach lokalnej polityki, lecz instrumentem, w którym poprzez konstruktywną debatę zwiększy się szansa na rozwój gminy. Zdaniem R. Krawczyka nie ma wątpliwości, że sposób komunikowania się powinien być oparty na dialogu społecznym ${ }^{10}$. Należy się zgodzić z tym stanowiskiem, ponieważ, po pierwsze, poprzez wspólny dialog można wpłynąć na wiele istotnych spraw, po drugie, wszelkie działania związane z przedstawieniem raportu prowadzą do wzrostu transparentności między organami gminy a jej mieszkańcami. Nadto wnikliwie sporządzony raport umożliwia dokonanie analizy poziomu rozwoju na przestrzeni kilku lat ${ }^{11}$.

Zgodnie $\mathrm{z}$ art. 28aa ust. 1 u.s.g. wójt lub burmistrz przedstawia radzie raport o stanie gminy co roku do 31 maja. Termin ten należy rozumieć $\mathrm{w}$ taki sposób, że do tego dnia raport powinien być przesłany radnym w skuteczny sposób ${ }^{12}$, a także udostępniony mieszkańcom poprzez zamieszczenie na stronie urzędu lub w Biuletynie Informacji Publicznej, aby zainteresowani mogli w odpowiednim czasie zapoznać się z jego treścia, przeanalizować ją i zabrać głos w debacie. Wprawdzie przepisy u.s.g. nie wskazują na to, kiedy najlepiej rozpocząć pracę nad raportem, co więcej, ustawodawca nie wprowadził jakichkolwiek konsekwencji związanych z niedotrzymaniem przez wójta końcowego

\footnotetext{
${ }^{9}$ C. Matysz, Komentarz do art. 28aa, w: B. Dolnicki i in., Ustawa o samorzadzie gminnym. Komentarz, Warszawa 2018, LEX nr 587759706.

${ }^{10}$ R. Krawczyk, Raport o stanie gminy, „Finanse Komunalne” 2019, nr 6, s. 6-16, LEX nr 151351145

${ }^{11}$ Ibidem.

12 Przez skuteczny sposób rozumie się dostarczenie raportu za pomocą poczty elektronicznej lub poczty tradycyjnej za potwierdzeniem otrzymania odbioru.
} 
terminu przedstawienia radzie raportu, lecz w piśmiennictwie ${ }^{13}$ zwraca się uwagę na to, aby prace rozpocząć wcześnie, tj. zaraz po zakończeniu roku kalendarzowego. Zdaniem autorki opracowania jest to właściwe posunięcie, gdyż zwiększa oczekiwany efekt końcowy dokumentu, tj. jego przejrzystość i skrupulatność. Już w początkowym etapie sporządzania raportu warto pomyśleć nad włączeniem mieszkańców w jego prace $^{14}$, należy bowiem pamiętać, że raport jest sporządzany nie tylko dla radnych, którzy z reguły są na bieżąco z informacjami gminy, ale i dla całej społeczności lokalnej. Warte podkreślenia jest to, że ustawodawca połączył rozpatrywanie raportu o stanie gminy z postępowaniem w sprawie udzielenia lub nieudzielenia wójtowi absolutorium $\mathrm{z}$ tytułu wykonania budżetu. W związku z tym, że uchwała w sprawie absolutorium powinna być podjęta najpóźniej do 30 czerwca, co wynika $\mathrm{z}$ art. 271 ust. 1 ustawy o finansach publicznych ${ }^{15}$, a raport powinien być sporządzony do 31 maja, to ryzykowne byłoby niedotrzymanie terminu przedstawienia raportu.

Całokształt regulacji prawnych dotyczących raportu pozwala przypisać mu trzy zasadnicze funkcje: (1) sprawozdawczą, (2) partycypacyjną i (3) oceniającą ${ }^{16}$. Pierwsza z nich związana jest z treścią raportu, od którego oczekuje się przedstawienia rzetelnych informacji o funkcjonowaniu gminy. Druga, partycypacyjna, umożliwia mieszkańcom uczestniczenie $w$ debacie. $Z$ kolei funkcja trzecia, oceniająca, jest oceną podjętych działań i decyzji oraz sposobu sprawowania funkcji wójta lub burmistrza. Zapewne jest powiązana $z$ instytucją wotum zaufania rady wobec wójta - po zakończeniu debaty, zgodnie z art. 28aa ust. 9 u.s.g., rada przeprowadza głosowanie nad udzieleniem bądź nieudzieleniem wójtowi czy burmistrzowi wotum zaufania. Instytucja wotum zaufania i możliwe konsekwencje jego nieudzielenia to niewątpliwie temat wymagający odrębnego rozważenia ${ }^{17}$.

\footnotetext{
${ }^{13}$ C. Matysz, op. cit.

${ }^{14}$ Przez włączenie mieszkańców w prace nad raportem autorka rozumie np. zorganizowanie panelu obywatelskiego na temat tego, co mieszkańcy chcą wiedzieć o swojej gminie.

${ }^{15}$ Ustawa z dnia 27 VIII 2009 r. o finansach publicznych (tekst jedn. Dz.U. 2019, poz. 869), dalej „u.f.p.”.

${ }^{16}$ S. Gajewski, Raport o stanie jednostki samorzadu terytorialnego, w: Ustawy samorzadowe. Nowe instytucje. Analiza z przykładami i wzorami dokumentów, Warszawa 2018.

${ }^{17}$ Artykuł 28aa ust. 10 u.s.g.: „W przypadku nieudzielenia wójtowi wotum zaufania $\mathrm{w}$ dwóch kolejnych latach rada gminy może podjać uchwałę o przeprowadzeniu referendum w sprawie odwołania wójta". Podjęcie przez radę gminy uchwały o przeprowadzeniu
} 
O tym, która z funkcji będzie dominowała, najprawdopodobniej zdecydują warunki lokalne i podłoże polityczne. Niemniej jednak należy pamiętać, że bezsprzecznie raport powinien służyć mieszkańcom i osobom tworzącym administrację lokalną. Mieszkańców ma informować i włączać do dyskusji, a kierownictwo administracyjne skłonić do strategicznej refleksji. Wszystko po to, by działania wspólnoty lokalnej były jak najbardziej efektywne.

$\mathrm{W}$ rozumieniu art. 1 ust. 1 u.s.g. mieszkańcy gminy tworzą z mocy prawa wspólnotę samorządową. Etymologicznie słowo „wspólnota" wywodzi się od słowa "wspólny”, które ma wiele znaczeń, w szczególności: (1) wspólny jako połączony, łączny, zorganizowany, zrzeszony, skupiony i powszechny; (2) wspólny jako publiczny, obywatelski, kooperatywny i społeczny; (3) wspólny jako wzajemny, wielostronny i zaprzyjaźniony ${ }^{18}$. Wspólnota charakteryzuje się więc pewnym stopniem zintegrowania społecznego, zdolnością do samoorganizacji w imię wspólnych celów oraz istnieniem wątków wspólnej świadomości społecznej, zdeterminowanej warunkami lokalnymi. B. Dolnicki, mówiąc o podmiocie samorządu, posługuje się pojęciem terytorialnej korporacji komunalnej. Oznacza to, że samorząd to sprawowanie administracji przez zbiorowość zainteresowanych osób. W przypadku samorządu terytorialnego mowa o osobach zamieszkałych na danym terenie ${ }^{19}$. Pogląd ten podziela E. Olejniczak-Szałowska, twierdząc, że wspólnota samorządowa jest grupą terytorialną gdyż podstawą jej powstania jest związanie członkostwa grupy z oznaczoną przestrzenią. Ludzi tych łączą sprawy i zależności, a więc wspólne interesy, które wiążą się ze wspólnym zamieszkiwaniem na danym terytorium ${ }^{20}$. Natomiast zdaniem A. Szewca w pojęciu wspólnoty gminnej mieszczą się dwa atrybuty o charakterze

referendum w sprawie odwołania wójta zainicjuje procedurę, która szczegółowo określona jest przepisami Ustawy z dnia 15 IX 2000 r. o referendum lokalnym (Dz.U. nr 88, poz. 985). Tym samym rada gminy, decydując się na takie działanie, musi być świadoma konsekwencji wynikających z przepisu art. 67 ust. 3 tego aktu, stanowiącego: „jeżeli w ważnym referendum o odwołanie wójta (burmistrza, prezydenta miasta) przeprowadzonym na wniosek rady gminy z innej przyczyny niż nieudzielenie absolutorium, przeciwko odwołaniu wójta (burmistrza, prezydenta miasta) oddano więcej niż połowę ważnych głosów, działalność rady gminy ulega zakończeniu z mocy prawa".

${ }^{18}$ D. Fleszer, Samorząd terytorialny jako wspólnota obywatelska, „Roczniki Administracji i Prawa" 2016, nr 16, Sosnowiec, s. 102.

${ }^{19}$ B. Dolnicki, Komentarz do art. 1, w: M. Augustyniak i in., Ustawa o samorzadzie gminnym. Komentarz, LEX nr 587293418.

${ }^{20}$ E. Olejniczak-Szałowska, Członkostwo wspólnoty samorzadowej, "Samorząd Terytorialny" 1996, nr 5, s. 3-13. 
wektorowym. Jeden określa relację danej wspólnoty do innych wspólnot gminnych, polegającą na jej oddzieleniu od tych wspólnot, drugi natomiast wyznacza relację wewnętrzną, zachodzącą pomiędzy wspólnotą jako całością, czyli ogółem mieszkańców gminy, a jej poszczególnymi członkami, określającą ich wzajemne obowiązki i prawa ${ }^{21}$.

Jak zostało wyrażone w art. 61 Konstytucji Rzeczypospolitej Polskiej22, każdy obywatel ma prawo do uzyskiwania informacji o działalności organów władzy publicznej oraz osób pełniących funkcje publiczne. Wyrok Wojewódzkiego Sądu Administracyjnego (WSA) w Poznaniu z dnia 15 stycznia 2020 r. wskazuje, że informacja publiczna to „każda informacja wytworzona przez władze publiczne, przez osoby pełniące funkcje publiczne oraz inne podmioty, które gospodarują mieniem publicznym, jak również informacje odnoszące się do wspomnianych władz, osób i innych podmiotów, niezależnie od tego, przez kogo zostały wytworzone ${ }^{\prime 23}$. Ponadto istotne znaczenie w kontekście pozyskania informacji ma zwiększenie aktywności społecznej w procesach zarządzania majątkiem publicznym. Zarządzanie, w przeciwieństwie do administrowania, powinno być procesem, który zawiera w sobie zarówno aktywność, jak i kreatywność ${ }^{24}$. Szczególna jest rola samorządu terytorialnego jako podmiotu inspirującego obywateli do aktywności. Jego pozycja w misji kształtowania ładu społecznego opartego na więziach społecznych, na wspólnych działaniach i na inwencji powinna stanowić motyw przewodni dla osiągania zbiorowego celu. Niewątpliwie możliwość decydowania o sprawach gminy wymaga najpierw ich identyfikacji, a możemy je wyczytać z treści raportu, następnie zaś ustalenia oczekiwań co do sposobu i formy ich realizacji.

\section{Treść raportu o stanie gminy}

Jak wskazano na wstępie, raport o stanie gminy w świetle art. 28aa ust. 2 u.s.g. zawiera podsumowanie działalności wójta bądź burmistrza w roku poprzednim, zwłaszcza zaś realizację polityk, programów i strategii oraz

${ }^{21}$ A. Szewc, Komentarz do art. 1 u.s.g., w: A. Szewc, G. Jyż, Z. Pławecki, Samorząd gminny. Komentarz, Warszawa 2012, LEX nr 587335223.

${ }^{22}$ Konstytucja Rzeczypospolitej Polskiej z dnia 2 IV 1997 r. (Dz.U. Nr 78, poz. 483 ze zm.).

${ }^{23}$ Wyrok WSA z 15 I 2020 r., sygn. IV SAB/Po 227/19, Legalis nr 2269588.

${ }_{24}$ A. Kumpiałowska, Good governance - omówienie koncepcji zarządzania publicznego, Legalis 2016. 
uchwał rady gminy i budżetu obywatelskiego. Takie brzmienie przepisu dowodzi, że w raporcie należałoby ująć wszelkie zagadnienia związane z działalnością wójta. Obligatoryjne jest przedstawienie realizacji polityk, programów i strategii, uchwał rady gminy oraz realizacji budżetu obywatelskiego. Swoboda w zakresie powyższych informacji przejawia się jedynie w sposobie prezentacji danych. Zdaniem W. Baranowskiej-Zając ${ }^{25}$ sformułowanie "działalność wójta w roku poprzednim" można traktować jako sformułowanie nieostre, które może być wypełnione treścią w zależności od charakteru i okoliczności danej gminy. Należy się z tym zgodzić, niemniej należy pamiętać o ryzyku prowadzącym do sytuacji, w której akcentowane będą przede wszystkim dobre strony wykonywanej działalności wójta, z pominięciem tych niesprzyjających organowi wykonawczemu.

Wydaje się, że raport, jak każde sprawozdanie, powinien rozpoczynać się od wprowadzenia, tj. krótkich informacji ogólnych. Należą do nich m.in.: położenie geograficzne, sytuacja demograficzna, rodzaj gminy (wiejska, miejsko-wiejska czy miejska), liczba jednostek organizacyjnych i pomocniczych gminy, samorządowych zakładów budżetowych, spółek komunalnych i jednostek kulturowych. Z tego względu, że sytuacja j.s.t. określana jest przez ustawodawcę jako "stan gminy”, zapewne wiąże się w znacznym stopniu $\mathrm{z}$ gospodarką finansową. W związku z tym gospodarka finansowa powinna być kolejnym zagadnieniem omawianym w raporcie. Mieszkańcy zwykle są zainteresowani sytuacją finansową, w szczególności dochodami i wydatkami gminy, a zwłaszcza tym, jak kształtował się udział dochodów własnych, udział wydatków majątkowych w wydatkach ogółem, jaki był poziom tzw. wolnych środków finansowych ${ }^{26}$ oraz wysokość dopłat $\mathrm{z}$ budżetu państwa na realizację zadań zleconych z zakresu administracji rządowej. Do grupy finansowej zaliczyć można również dotacje pozyskane spoza urzędu oraz wskaźniki wieloletniej prognozy finansowej, a ponadto udział środków budżetu partycypacyjnego w wydatkach gminy oraz wysokość funduszu sołeckiego będącego prawną instytucją, o której decyduje rada gminy, podejmując stosowną uchwałę ${ }^{27}$, w której wyraża zgodę albo nie wyraża zgody na wyodrębnienie funduszu. O przeznaczeniu

\footnotetext{
${ }^{25}$ W. Baranowska-Zając, op. cit.

${ }^{26}$ Poziom wolnych środków w rozumieniu art. 217 ust. 2 pkt 6 Ustawy z dnia 27 VIII 2009 r. o finansach publicznych (Dz.U. Nr 157, poz. 1240) jest traktowany jako nadwyżka na rachunku bieżącym j.s.t.

${ }^{27}$ Ustawa z dnia 21 II 2014 r. o funduszu sołeckim (Dz.U. 2014 poz. 301).
} 
zadań do realizacji w ramach funduszu sołeckiego decydują natomiast mieszkańcy sołectw.

Informacja o realizacji polityk, programów i strategii to część raportu, w którym zawarty jest proces wykonywania zadań, w tym zaangażowania innych podmiotów realizujących działania wskazane przez wójta bądź burmistrza. Niewątpliwie wiele zależy od realnych możliwości j.s.t., aktywność gmin może być bowiem różna i zwykle jest uzależniona od warunków miejscowych, przestrzennych i społeczno-kulturowych oraz możliwości finansowych. W odniesieniu do programów gminnych należy pamiętać, że większość z nich jest podejmowana przez organ stanowiący gminy ${ }^{28}$ i o ile ich treść jest oczywista i nie budzi zastrzeżeń, bo wynika z norm ustawowych, to refleksja i dyskusja w debacie może dotyczyć sposobu ich realizacji i wysokości środków finansowych przeznaczonych na ich wykonanie. Należy w tym miejscu wspomnieć także o programach rządowych realizowanych w j.s.t., np. o Programie powszechnej nauki pływania „Umiem pływać” skierowanym do uczniów klas I-III szkół podstawowych czy rocznym programie "Maluch+" Ministerstwa Rodziny, Pracy i Polityki Społecznej. Omówienie realizacji tych programów w raporcie jest wskazane, gdyż nie ma znaczenia, czy zostały one przyjęte przez organ stanowiący, czy też ustanowił je inny podmiot, a organ wykonawczy bierze udział w ich realizacji z mocy prawa, porozumienia bądź umowy ${ }^{29}$.

${ }^{28}$ Rada gminy podejmuje programy w zakresie wykonywania zadań własnych. Są to np.: Program przeciwdziałania przemocy w rodzinie na mocy Ustawy z dnia 29 VI 2005 r. o przeciwdziałaniu przemocy w rodzinie (tekst jedn. Dz.U. 2020, poz. 218), Program wspierania rodziny na podstawie Ustawy z dnia 8 VI 2011 r. o wspieraniu rodziny i systemie pieczy zastępczej (tekst jedn. Dz.U. 2020, poz. 821), roczny Program współpracy $\mathrm{z}$ organizacjami pozarządowymi oraz podmiotami wymienionymi $\mathrm{w}$ art. 3 ust. 3 na podstawie Ustawy z dnia 24 IV 2003 r. o działalności pożytku publicznego i o wolontariacie (tekst jedn. Dz.U. 2019, poz. 688), gminny Program profilaktyki i rozwiązywania problemów alkoholowych na podstawie Ustawy z dnia 26 X 1982 r. o wychowaniu w trzeźwości i przeciwdziałaniu alkoholizmowi (tekst jedn. Dz.U. 2019, poz. 2277), gminny Program przeciwdziałania narkomanii na podstawie Ustawy z dnia 29 VII 2005 r. o przeciwdziałaniu narkomanii (tekst jedn. Dz.U. 2019, poz. 852), Program opieki nad zwierzętami bezdomnymi oraz zapobiegania bezdomności zwierząt na podstawie Ustawy z dnia 21 VIII 1997 r. o ochronie zwierząt (tekst jedn. Dz.U. 2020, poz. 638), Program ochrony środowiska na podstawie Ustawy z dnia 27 IV 2001 r. Prawo Ochrony Środowiska (tekst jedn. Dz.U. 2019, poz. 1396), Program opieki nad zabytkami na podstawie Ustawy z dnia 23 VII 2003 r. o ochronie zabytków i opiece nad zabytkami (tekst jedn. Dz.U. 2020, poz. 282), Program wspierania edukacji uzdolnionych dzieci i młodzieży na podstawie Ustawy z dnia 7 IX 1991 r. o systemie oświaty (tekst jedn. Dz.U. 2019, poz. 1481).

${ }^{29}$ B. Wilk, Rozdział III. Treść raportu o stanie JST, w: Raport o stanie JST, Warszawa 2020. 
W ocenie autorki opracowania należy również rekomendować uwzględnienie w raporcie podsumowania działalności z punktu widzenia komórek organizacyjnych i jednostek organizacyjnych j.s.t., w tym samorządowych zakładów budżetowych. Plusem takiego rozwiązania jest pokazanie mieszkańcom, w jaki sposób działa szeroko pojęta gmina. Należałoby zwrócić uwagę na takie zagadnienia, jak: stan zasobów komunalnych i stopień ich amortyzacji, plan ich wykorzystania oraz liczba wszczętych postępowań eksmisyjnych, zasady zarządzania mieniem gminnym i kierunki gospodarowania w kontekście zakupu i sprzedaży oraz stan zabytków będących we władaniu gminy. W ramach omówienia infrastruktury raport powinien zawierać informacje o długości sieci kanalizacyjnej, gazowej i wodociągowej, liczbie gospodarstw domowych posiadających przyłącza i korzystających z danego rodzaju sieci. Powinien też prezentować stan infrastruktury drogowej, w tym zawierać wzmiankę o długości ścieżek rowerowych i chodników.

Zgodnie z art. 33 ust. 5 u.s.g. wójt (burmistrz) jest zwierzchnikiem służbowym kierowników gminnych jednostek organizacyjnych. W związku z tym może się zwrócić o przedstawienie informacji o działalności kierowanych przez nich jednostek, tj. szkół, przedszkoli, żłobków (publicznych i niepublicznych), a także oddziałów specjalnych i klubów dziecięcych. Z raportu powinno wynikać, jaka liczba uczniów zamieszkuje gminę, a jaka gminy sąsiednie. Ma to znaczenie w odniesieniu do subwencji oświatowej pochodzącej z budżetu państwa i budżetu danej gminy. Informacją pożądaną jest liczba etatów w szkołach, z podziałem nauczycieli na określone stopnie awansu zawodowego, oraz liczba stypendiów przyznana uczniom.

W zakresie ochrony środowiska niezbędne jest wskazanie udziału gminy w programach ochrony środowiska, informacji dotyczących gospodarki niskoemisyjnej i gospodarki śmieciowej, w tym liczby wysypisk i punktów selektywnej zbiórki odpadów, ponadto umieszczenie wykazu funkcjonujących na terenie gminy zakładów uciążliwych dla środowiska.

W art. 28aa ust. 2 u.s.g. ustawodawca wskazał również, że raport powinien zawierać ocenę realizacji uchwał rady gminy. $Z$ pewnością nie wszystkie uchwały będą miały status wykonania w danym roku, realizacja niektórych z nich jest bowiem rozłożona na kilka lat. Należy zatem przyjąć, że nie chodzi tylko o uchwały podjęte w poprzednim roku kalendarzowym, ale o wszystkie, które były wykonywane w danym roku.

Ostatnią grupą są informacje dotyczące realizacji budżetu obywatelskiego. Zgodnie z art. 5a ust. 3-7 u.s.g. budżet obywatelski jest formą 
konsultacji społecznych, sprowadzającą się do wyboru przez mieszkańców w głosowaniu bezpośrednim zadań do realizacji, które następnie są włączane do budżetu gminy poprzez podjęcie stosownej uchwały rady.

Na koniec należy zauważyć, że choć raporty dotyczą jednego roku, to wszystkie zagadnienia warto ukazać w dłuższej perspektywie czasowej po to, by mieszkaniec gminy miał możliwość oceny postępu lub regresu w odniesieniu do zaspokajania jego potrzeb oraz priorytetów zadań wykonywanych przez samorząd ${ }^{30}$.

\section{Debata publiczna nastawiona na kooperację kluczem do rozwoju gminy}

W debacie publicznej nie chodzi tylko o partycypację społeczna, która odsyła wprost do włączenia mieszkańców w sprawy publiczne, ale też o przejrzystość spraw publicznych, która implicite odsyła do idei publicznej przestrzeni. W przestrzeni publicznej wszyscy zainteresowani zyskują dostęp do informacji i wtedy dopiero mogą formułować racjonalne oceny i postulaty dotyczące działalności organu wykonawczego. Najistotniejsza dla debaty jest "scena" sfery publicznej, w której mogą się oni spotkać i stać się "widzialni" dla wszystkich zainteresowanych obserwatorów ${ }^{31}$. Sfera publiczna jest miejscem ujawniania woli zbiorowej mieszkańców. Oznacza przestrzeń, w obrębie której mieszkańcy mogą swobodnie, choć przestrzegając pewnych zasad ${ }^{32}$, ujawniać swoje poglądy, przedstawiać racje i prezentować różne punkty widzenia, opinie, spostrzeżenia i argumenty.

Debata jest owocna wtedy, gdy jej uczestnicy są do niej odpowiednio przygotowani, zwłaszcza gdy posiadają wiedzę w zakresie działalności organu wykonawczego, w tym wiedzę o problemach związanych z tą działalnością. Niewątpliwie dyskusja nad problemami powinna być traktowana przez organ wykonawczy gminy jako wyraz zainteresowania

\footnotetext{
${ }^{30}$ R. Krawczyk, op. cit.

${ }^{31}$ Ustawą o zmianie niektórych ustaw w celu zwiększenia udziału obywateli w procesie wybierania, funkcjonowania i kontrolowania niektórych organów publicznych wprowadzono obowiązek transmitowania i utrwalania obrad organu stanowiącego j.s.t. za pomocą urządzeń rejestrujących obraz i dźwięk. Nagrania obrad udostępnia się w Biuletynie Informacji Publicznej i na stronie internetowej j.s.t. (art. 20 ust. 1b u.s.g.). Dzięki temu każdy zainteresowany gminą mieszkaniec może śledzić na bieżąco to, co się dzieje podczas sesji rady.

${ }^{32}$ Mowa o zasadach proceduralnych, prawnych i obyczajowych. W przestrzeni publicznej ludzie nie powinni zachowywać się dowolnie.
} 
problemami, a nie jako negatywna strategia komunikacyjna. Ważne jest stworzenie apolitycznej płaszczyzny debaty i przestrzeganie reguł nastawionych na kooperację, gdyż tylko wtedy wyniki debaty mogą być satysfakcjonujące dla wszystkich jej uczestników. Etymologicznie pojęcie "kooperacja” wywodzi się z łacińskiego cooperatio (co - razem, operari - pracować). Przyjęta definicja wskazuje, że kooperacja stanowi współpracę grupy osób ${ }^{33}$. Nie budzi wątpliwości, że aby można było mówić o kooperacji, musi występować poczucie wspólnych interesów, dążenie do zrealizowania zamierzonych celów, zdolność do kompromisów i podejmowanie optymalnych decyzji ${ }^{34}$.

W debacie nad raportem o stanie gminy istotne jest: (1) włączenie mieszkańców w załatwianie określonych spraw; (2) zyskanie przychylności mieszkańców wobec działań zmierzających do osiągnięcia celów uznanych za ważne; (3) wyjaśnienie mieszkańcom motywów danego rozwiązania problemu i przedstawienie innych możliwych sposobów rozwiązania problemów ${ }^{35}$. Jeżeli administracji samorządowej będzie zależało na tym, by wykorzystać raport do włączenia się mieszkańców w sprawy publiczne, zainteresowanie ich działalnością organów oraz poznania ich opinii na temat kierunku działalności, to drobiazgowe dane ustąpić muszą skonkretyzowaniu problemów i wyzwań. Im większy udział mieszkańców w życiu społeczności lokalnej na różnych płaszczyznach, tym szybciej może się ono rozwijać. Nie ulega wątpliwości, że samorząd gminny porusza się $\mathrm{w}$ specyficznym środowisku, w którym opinie i postrzeganie j.s.t. przez jej mieszkańców w znacznej mierze warunkują możliwość podejmowania przez władze lokalne poszczególnych przedsięwzięć.

W kwestii udziału mieszkańców w debacie nad raportem istnieje, jak zaakcentowano wcześniej, wymóg spełnienia ustawowych warunków, o których mowa w art. 28 aa ust. 7 u.s.g. Z przepisu tego wynika, że warunkiem udziału mieszkańca w debacie jest dokonanie pisemnego zgłoszenia skierowanego do przewodniczącego rady najpóźniej w dniu poprzedzającym zwołanie sesji. Zgłoszenie powinno zostać poparte podpisami określonej liczby osób, w zależności od liczby mieszkańców gminy. W gminach do 20000 mieszkańców zgłoszenie powinno być poparte podpisami co najmniej 20 osób, a w gminach powyżej

${ }^{33}$ B. Stępień, Międzynarodowa kooperacja gospodarcza z polskiej perspektywy, Warszawa 2011, s. 15.

${ }^{34}$ L. Gilejko, R. Towalski, Partnerzy społeczni. Konflikty, kompromisy, kooperacja, Warszawa 2002, s. 125-137.

${ }^{35}$ D. Fleszer, op. cit., s. 109. 
20000 mieszkańców podpisami co najmniej 50 osób. Ponadto zgodnie $\mathrm{z}$ art. 28 aa ust. 8 u.s.g. zdanie ostatnie wprowadzono ograniczenie liczby mieszkańców mogących brać udział w debacie do 15 osób. Możliwe jest jednak zwiększenie liczby mieszkańców przez radę w wyniku podjęcia stosownej uchwały. O ile słuszny wydaje się wymóg zgłoszenia mieszkańca do debaty, choćby dla zachowania porządku organizacyjnego i orientacji, ile osób zamierza wziąć udział w debacie, to uzyskanie wymaganej liczby podpisów, w ocenie autorki, można postawić pod znakiem zapytania, ponieważ zebranie podpisów może w praktyce okazać się utrudnieniem. Niemniej jednak wydaje się, że błędna byłaby wykładnia przepisów uniemożliwiająca radzie gminy odstąpienie od wymogu żądania podpisów poparcia. Celem ustawy z.u.o.u., jak zostało wyrażone $\mathrm{w}$ jej tytule, jest zwiększenie udziału obywateli $\mathrm{w}$ funkcjonowaniu j.s.t., absurdalne byłoby zatem interpretowanie przepisów w sposób uniemożliwiający radzie, w ramach jej ustrojowej autonomii, zastosowanie rozwiązań, które jeszcze bardziej służą ułatwianiu mieszkańcom gminy udziału w debacie. W tym miejscu można wysunąć wniosek de lege ferenda zrezygnowania z uzyskania określonej liczby podpisów. Na uwagę zasługuje fakt, że ustawodawca nie wypowiada się na temat wieku mieszkańców zamierzających zabrać głos w debacie. Wydaje się, że należałoby postulować, aby dyskusja nad raportem nie wykluczała prawa młodzieży do zabierania głosu.

Oprócz właściwych przepisów prawa i rozwiązań organizacyjnych stwarzających możliwość zaangażowania się we wspólnotę, skuteczność rozwoju samorządu lokalnego warunkuje ciągła aktywizacja społeczna i integracja wewnętrzna zbiorowości. Zdaniem H. Kotarskiego udział obywateli w życiu publicznym wiąże się ze społeczeństwem obywatelskim ${ }^{36}$. Z kolei S. Iwanowski podkreśla, że w społeczeństwie obywatelskim podstawowe znaczenie ma inicjatywa obywateli skierowana na współuczestniczenie, a zarazem wspólne rozwiązywanie spraw uznanych za istotne dla całej społeczności ${ }^{37}$. Innymi słowy, społeczeństwo obywatelskie to takie, w którym obywatele mają zdolność niezależnego działania i świadomego uczestniczenia w życiu publicznym. Aktorzy debaty poprzez współdziałanie dążą do osiągnięcia wspólnego celu,

${ }^{36}$ H. Kotarski, Kapitał społeczny mieszkańców województwa podkarpackiego jako element budowy wspólnoty obywatelskiej, w: Samorząd terytorialny - wspólnota polityczna czy obywatelska?, pod red. P. Romaniuka, C. Bugdalskiego, Bielsko-Biała 2013, s. 126 i n.

${ }^{37} \mathrm{~S}$. Iwanowski, Prawne formy organizowania się społeczeństwa, "Samorząd Terytorialny" 2010, nr 1-2, s. 22. 
czyli rozwoju lokalnego. Analizy raportu o stanie gminy oraz aktywne uczestnictwo mieszkańców poprzez dyskusję i modyfikację przyjętych wcześniej założeń pozwalają osiągnąć to, że każdy kolejny raport prowadzi do bardziej satysfakcjonującego rozwoju lokalnego. Rozwój lokalny jest pojęciem wielowymiarowym, postrzeganym jako postęp, progresja i wzmacnianie efektywności. Związany jest z lokalną skalą działalności społeczno-gospodarczej i obejmuje lokalne środowisko. Rozwój jest procesem ukierunkowanym z punktu widzenia potrzeb społeczności, dostępnych zasobów oraz poprzez zaangażowanie w jego przebieg zarówno społeczności lokalnej, jak i struktur samorządu terytorialnego oraz innych organizacji lub instytucji. Niezwykle ważnym zasobem stanowiącym potencjał w rozwoju lokalnym jest kapitał społeczny. Mieszkańcy poprzez umiejętność współpracy, zaufanie i dobre relacje tworzą warunki do skoordynowania działań na rzecz określonych celów. Rozwój lokalny odnosi się do dwóch podstawowych terminów: terytorium, przez które należy rozumieć gminę, i zmian, jakie mają w niej zachodzić. Przez terytorium należy pojmować: (1) środowisko przestrzenne wyznaczone granicami administracyjnymi; (2) wspólnotę mieszkańców żyjącą w przestrzeni; (3) istniejące organizacje o charakterze społecznym, kulturowym, technologicznym i gospodarczym; (4) system zarządzania jednostką terytorialna, na którą składają się kierownictwo administracyjne i mieszkańcy.

Nie ulega wątpliwości, że podmiotowe traktowanie mieszkańców prowadzi do społecznych impulsów w działaniu, a w konsekwencji do społecznej aprobaty. Samorząd lokalny, dzięki możliwościom włączania do kooperacji wielu aktorów społecznych, odgrywa szczególną rolę w rozwoju gminy. Pożądane byłoby, aby mieszkańcy aktywnie współuczestniczyli w decyzjach dotyczących ich spraw. Przyjmowanie postawy oceniającej, krytykującej, kwestionującej wszelkie poczynania nie stanowi płaszczyzny współpracy. Warte podkreślenia jest to, że tylko wówczas, gdy wspólnota lokalna jest jednocześnie wspólnotą obywatelska, możliwe jest pełne wykorzystanie posiadanego przez nią potencjału.

\section{Koncepcja demokracji kooperacyjnej w Niemczech}

W ostatnich latach liczba instrumentów oddziaływania na sprawy lokalne w Niemczech imponująco wzrosła. Ma na to wpływ proces modernizacji sfery publicznej związany z takimi reformami, jak: 
(1) reorganizacja wewnętrzna struktur władzy lokalnej w celu wzmocnienia jej efektywności (w ramach koncepcji New Public Management), w której mieszkaniec gminy staje się klientem i konsumentem administracji ${ }^{38}$; (2) demokratyzacja polegająca na rozszerzeniu form partycypacji politycznej obywateli, w szczególności koncepcja wspólnoty obywatelskiej, Bürgerkommune.

Koncepcja Bürgerkommune odgrywa istotną rolę w zaangażowaniu obywatela $\mathrm{w}$ funkcjonowanie wspólnoty lokalnej. By to zaangażowanie pobudzić, należy stworzyć obywatelowi nowe ścieżki partycypacji. W tym miejscu pojawia się koncepcja demokracji kooperacyjnej ${ }^{39}$. Pod tym pojęciem rozumiane są procesy dotyczące wspólnoty lokalnej, które uwzględniają udział obywateli i ich organizacji w formułowaniu oraz realizowaniu celów politycznych, które zorientowane są na dialog i współpracę pomiędzy obywatelem a władzami lokalnymi dla osiągnięcia jak najlepszych rezultatów (unter kooperativen Demokratie verstehen wir alle nicht gesetzlich geschriebenen, dialogisch orientierten und auf kooperative Problemlösungen angelegten Verfahren der Bürger- und Verbändebeteiligung an der Politikformulierung und Politikumsetzung ${ }^{40}$. Jest to zatem konieczność funkcjonowania procesów zapewniających udział mieszkańców w budowaniu koncepcji i kierunków działań w danej społeczności oraz uznanie, że obywatel wniesie własne zasoby dla realizacji celów wspólnoty, np. przejmie odpowiedzialność za utrzymanie małej infrastruktury w parkach lub na placach zabaw.

W niemieckiej koncepcji ważne jest założenie, że relacje pomiędzy obywatelem a wspólnotą samorządową są wielopłaszczyznowe. Pierwsza płaszczyzna odnosi się do obywatela, który podejmuje decyzje poprzez wybory i referenda, druga do obywatela jako klienta wytworzonych usług, a trzecia do obywatela jako współkształtującego wspólnotę i koproducenta usług użyteczności publicznej. Nie ulega wątpliwości, że wspieranie obywatelskiego zaangażowania, w rozumieniu społecznego współkreowania rozwoju wspólnoty, determinuje coraz szerszą akceptację. Z jednej strony jest to dobra wola i gotowość ze strony gminy,

${ }^{38}$ Elementem reform była prywatyzacja infrastruktury i usług komunalnych bądź wprowadzenie form partnerstwa publiczno-prywatnego.

${ }^{39}$ A. Mirska, Demokracja lokalna w Niemczech, w: I. Bokszczanin, A. Mirska, Demokracja lokalna w państwach Europy, Warszawa 2014, s. 186.

${ }^{40} \mathrm{~J}$. Bogumil, Modernisierung lokaler Politik - Kommunale Entscheidungsprozesse im Spannungsfeld zwischen Parteienwettbewerb, Verhandlungswängen und Ökonomisierung, Baden-Baden 2001, s. 212. 
z drugiej natomiast niezbędna aktywność i zaangażowanie obywatela. Kwintesencją jest więc nakierowanie na kooperację i dialog pomiędzy mieszkańcami, organami władzy lokalnej a administracją lokalną, czyli tzw. demokracja kooperacyjna, która ma nie zastępować, ale uzupełniać i wzbogacać demokrację tradycyjną ${ }^{41}$.

Niemieckie samorządy decydują się na wprowadzenie różnych form uczestnictwa obywatela w kreowaniu wspólnoty. Niemniej pomiędzy krajami związkowymi istnieją różnice uzależnione od oczekiwań mieszkańców. Duże znaczenie ma proces uczenia się samorządów oraz poszukiwania przykładów dobrych praktyk, które mogą stanowić inspirację dla własnych działań. Śledząc poczynania poszczególnych samorządów komunalnych, można wskazać, że najczęściej stosowane formy angażowania mieszkańców w sprawy wspólnoty w ramach demokracji kooperacyjnej występują pod nazwami: komórki planowania (Planungszellen), fora obywatelskie (Bürgerforen), okrągłe stoły (runde Tische), konferencje dzielnicowe (Stadtteilkonferenzen), budżet partycypacyjny (Bürgerhaushalt) - są to ciała konsultacyjno-opiniodawcze, które dają obywatelowi możliwość intensywnego zaangażowania się na płaszczyźnie lokalnej.

Nie ulega wątpliwości, że wszystkie te formy w ramach demokracji kooperacyjnej są wdrażane przez władze lokalne, by uzyskać większą akceptację podejmowanych decyzji oraz zaprezentować się jako bürgerfreundlich (przyjazny dla obywatela). Nowoczesny niemiecki samorząd to taki, w którym są praktykowane instrumenty uczestnictwa obywatela w życiu publicznym, choć niewątpliwie mogą one spowolnić procesy decyzyjne.

Demokracja lokalna, aby mogła funkcjonować, nakłada na wszystkich obowiązek uczestnictwa ${ }^{42}$. Badacze niemieckiej demokracji są zgodni, że wskutek wprowadzenia różnych form współdziałania w ramach koncepcji demokracji kooperacyjnej członkowie wspólnot lokalnych uzyskali silną pozycję w komunalnych procesach politycznych jak nigdy dotąd ${ }^{43}$. Rzecz jasna sam fakt istnienia szerokiego spektrum form współdziałania nie wystarczy, by stały się one ważnym elementem demokracji lokalnej. Decydujące będzie regularne i skuteczne stosowanie

\footnotetext{
${ }^{41}$ Ibidem, s. 214.

${ }^{42}$ R. Kapuściński, Lapidarum V, Warszawa 2002, s. 29.

${ }^{43}$ O.W. Gabriel, Die Bürgergemeinde als neues Leitbild der Kommunalpolitik - Anspruch und Wirklichkeit, w: Die regierbare Stadt, Hrsg. von W. Schuster, K. Murawski, Stuttgart 2002, s. 140.
} 
tych instrumentów i przybliżenie administracji lokalnej do obywatela. Nie bez powodu pierwszy niemiecki prezydent Theodor Heuss ${ }^{44} \mathrm{w}$ jednym z przemówień powiedział "Gmina jest ważniejsza niż państwo, a w gminie najważniejsi są obywatele".

\section{Podsumowanie}

Samorząd terytorialny to jedna z najstarszych form samorządu. Wykonuje zadania publiczne na rzecz rozwoju j.s.t. Raporty powinny dawać odpowiedź na pytanie o jakość życia oraz informować o poziomie rozwoju samorządu. Nie można utożsamiać "stanu gminy” tylko z działalnością wójta, bo gdyby przyjąć takie założenie, to raport zostałby przekształcony w narzędzie do politycznego rozliczania wójta.

W debacie nad raportem należy szukać korzyści wynikających z możliwości komunikowania się organów administracji publicznej ze społeczeństwem. Przedstawianie raportów to doskonała okazja, aby wspólnie z mieszkańcami zastanowić się, jaki etap współpracy udało się osiągnąć - rozważyć jej mocne i słabe strony. Bez wątpienia debata nad raportem jest procesem wzajemnego oddziaływania jej uczestników. We wzajemnych działaniach zakłada się współdziałanie, które należy postrzegać jako koncepcję demokracji kooperacyjnej prowadzącą do rozwoju gminy. Nie ulega wątpliwości, że rozwiązywanie problemów w sferze publicznej wymaga połączonych i skoncentrowanych wysiłków wszystkich partnerów społecznych.

Prawidłowe pojmowanie instytucji raportu i debaty nad nim jest istotne, gdyż za sprawą uczestniczenia mieszkańców w zarządzaniu sprawami lokalnymi można się przyczynić do pozytywnych zmian $\mathrm{w}$ funkcjonowaniu gminy, $\mathrm{tj}$. wzrostu efektywności gospodarki i jakości życia obywateli. Nie bez znaczenia jest też rola przedstawicieli administracji publicznej, ponieważ to na nich ciąży obowiązek informowania i zachęcania społeczeństwa do angażowania się w życie publiczne. Ewolucja obywatelskiego zaangażowania w sprawy wspólne to niewątpliwie szansa na lepsze funkcjonowanie samorządu terytorialnego.

${ }^{44}$ Theodor Heuss, prezydent sprawujący urząd w latach 1949-1959, cytat pochodzi z jego przemówienia z okazji odsłonięcia pomnika Heinricha Friedricha Karla barona vom und zum Stein, uważanego za twórcę samorządu terytorialnego na terenie Niemiec. 


\section{THE REPORT ON THE CONDITION OF THE LOCAL COMMUNITY AND THE DEBATE THEREON IN THE LIGHT OF THE GERMAN CONCEPT OF COOPERATIVE DEMOCRACY}

\section{S u m mary}

Under the Act of 11th January 2018 amending certain acts in order to increase the participation of citizens in the process of selecting, functioning and controlling certain public authorities, the legislator has amended the provisions of all three constitutional acts, i.e. on local community self-government, district self-government and voivodeship self-government. The amendments concern, inter alia, the introduction of a mandatory institution, which is the report on the condition of the local community. Although the institution of the report refers to all levels of local self-government, this study concerns the local community, i.e. the self-government which is closest to its inhabitants, and which deals with the greatest number of issues affecting the quality of their life.

The report on the condition of the local community is a form of presenting the issues listed in Article 28 aa section 2 of the Act on the Local Community Self-government, i.e. "the report shall include the summary of the activities implemented by the local community administrator in the previous year, in particular the implementation of policies, programmes and strategies, resolutions of the local community council and the citizens' budget". In addition to the obligation of presenting the annual report on the condition of the local community, there is a need for a debate with the participation of both councillors and local residents. This debate certainly provides an opportunity for direct communication between executive authorities and society. Moreover, a constructive and meaningful debate boosts the effectiveness of the actions undertaken by the local community administrator, which as a result may contribute to positive changes in how the local community functions, i.e. an increase in the effectiveness of the economy and in citizens' quality of life. Following the ideas of German solutions in responding to local issues, the study attempts to present the institution of the report as a concept of cooperative democracy. The current proliferation of local democracy and the accompanying mechanisms of the new institutions may lead to broadly understood improvements in the conditions of local self-government residents.

Keywords: local community - report - debate

\section{LITERATURA}

Baranowska-Zając W., Obowiązek przedstawienia raportu o stanie gminy jako instrumentu wzmocnienia pozycji rady gminy wobec wójta (burmistrza, prezydenta miasta), "Samorząd Terytorialny" 2019, nr 4, LEX nr 151349430.

Bogumil J., Modernisierung lokaler Politik - Kommunale Entscheidungsprozesse im Spannungsfeld zwischen Parteienwettbewerb, Verhandlungswängen und Ökonomisierung, Baden-Baden 2001. 
Dolnicki B., Komentarz do art. 1, w: M. Augustyniak i in., Ustawa o samorządzie gminnym. Komentarz, LEX nr 587293418.

Fleszer D., Samorzad terytorialny jako wspólnota obywatelska, „Roczniki Administracji i Prawa" 2016, nr 16, Sosnowiec.

Gabriel O.W., Die Bürgergemeinde als neues Leitbild der Kommunalpolitik - Anspruch und Wirklichkeit, w: Die regierbare Stadt, Hrsg. von W. Schuster, K. Murawski, Stuttgart 2002.

Gajewski S., Raport o stanie jednostki samorzadu terytorialnego, w: Ustawy samorzadowe. Nowe instytucje. Analiza z przykładami i wzorami dokumentów, Warszawa 2018.

Gilejko L., Towalski R., Partnerzy społeczni. Konflikty, kompromisy, kooperacja, Warszawa 2002.

Iwanowski S., Prawne formy organizowania się społeczeństwa, "Samorząd Terytorialny” 2010, nr 1-2.

Kapuściński R., Lapidarum V, Warszawa 2002.

Kotarski H., Kapitat społeczny mieszkańców województwa podkarpackiego jako element budowy wspólnoty obywatelskiej, w: Samorząd terytorialny - wspólnota polityczna czy obywatelska?, pod red. P. Romaniuka, C. Bugdalskiego, Bielsko-Biała 2013.

Krawczyk R., Raport o stanie gminy, "Finanse Komunalne" 2019, nr 6, LEX nr 151351145.

Kumpiałowska A., Good governance - omówienie koncepcji zarządzania publicznego, Legalis 2016.

Matysz C., Komentarz do art. 28aa, w: B. Dolnicki i in., Ustawa o samorzadzie gminnym. Komentarz, Warszawa 2018, LEX nr 587759706

Mirska A., Demokracja lokalna w Niemczech, w: I. Bokszczanin, A. Mirska, Demokracja lokalna w państwach Europy, Warszawa 2014.

Olejniczak-Szałowska E., Członkostwo wspólnoty samorządowej, „Samorząd Terytorialny" 1996, nr 5.

Stępień B., Międzynarodowa kooperacja gospodarcza z polskiej perspektywy, Warszawa 2011.

Szewc A., Komentarz do art. 1 u.s.g., w: A. Szewc, G. Jyż, Z. Pławecki, Samorząd gminny. Komentarz, Warszawa 2012, LEX nr 587335223.

Wilk B., Rozdział III. Treść raportu o stanie JST, w: Raport o stanie JST, Warszawa 2020.

Witalec W., Raport o stanie jednostki samorzadu terytorialnego jako instrument oceny działalności jej organu wykonawczego, „Finanse Komunalne” 2019, nr 9, LEX nr 151354933. 